Acta medico-historica Rigensia (2019) XII: 67-91

doi:10.25143/amhr.2019.XII.03

Florian Steger, Maximilian Schochow

\title{
Closed Venereology Wards in the German Democratic Republic
}

\begin{abstract}
Over the 40-year existence of the German Democratic Republic (GDR), multiple thousands of women have been committed to closed venereology wards. The system of compulsory hospitalisation to closed venereology wards established in the GDR was based on the Soviet healthcare system. Its purpose was not simply to sanction behavior that diverged from the prescribed socialist norm but also to educate women in accordance with socialist standards. The involuntarily committed women in the GDR were treated by measures of politicised medicine. This medicine was shaped and executed by actors who imposed their own standards on the victimised women daily. Moreover, all closed venereology wards in the GDR were monitored by the Ministry of State Security through a network of inofficial informants.

Keywords: East Germany, education, Ministry of State Security, patient isolation, physician-patient relations, political activities, sexually transmitted diseases.
\end{abstract}

\section{Introduction}

In the communist East Germany (GDR - German Democratic Republic), various institutions such as schools, asylums and companies were intended to prepare girls and women for their double roles as both workers and mothers. ${ }^{1}$ These double roles were supported by social and demographic policy measures including public childcare, pregnancy

${ }^{1}$ Anna Kaminsky, Frauen in der DDR (Berlin: Ch. Links Verlag, 2013). 
leave, and parental allowances. ${ }^{2}$ If girls and women resisted their prescribed roles as working mothers, they could not only be criminalised as "asocial" but also could be interned in prisons or in special residential institutions that frequently resembled youth correction facilities, the so-called Jugendwerkhöfe. ${ }^{3}$ After the Second World War, another total institution ${ }^{4}$ was established in the Soviet Occupation Zone (SOZ) and in the GDR closed venereology wards. Beginning in the middle of 1940s, about ten closed venerological wards were established, among others in Berlin, Dresden, Erfurt, Gera, Halle (Saale), Leipzig, Rostock, and Schwerin. ${ }^{5}$

The main objective of these facilities was not only to treat venereal diseases but to discipline girls and women who did not conform to the standards of the communist society. If suspected of having a venereal disease, girls as young as 12 years (or older) and women could be involuntarily committed to such wards. ${ }^{6}$ The patients were medically treated without prior information or any consent. As a result, their physical integrity was harmed. The women were disciplined, isolated, and - consequently - heavily traumatised. Some of the physicians working directly in those venereology wards were also unofficial informants for the Ministry of State Security (in German, Ministerium für Staatssicherheit; short: MfS or colloquial: Stasi). Other physicians, who were inofficial informants of the MfS operated in higher positions and were responsible for entire districts, larger areas, and more patients. ${ }^{7}$

2 Manfred G. Schmidt, Sozialpolitik der DDR (Wiesbaden: VS Verlag für Sozialwissenschaften, 2004).

3 Sven Korzilius, “Asoziale” und "Parasiten" im Recht der SBZ, DDR. Randgruppen im Sozialismus zwischen Repression und Ausgrenzung (Köln, Weimar, Wien: Böhlau, 2004).

4 Erving Goffman, Asyle. Über die soziale Situation psychiatrischer Patienten und anderer Insassen (Frankfurt am Main: Suhrkamp, 1995).

5 Florian Steger and Maximilian Schochow, Disziplinierung durch Medizin. Die geschlossene Venerologische Station in der Poliklinik Mitte in Halle (Saale) 1961 bis 1982 (Halle (Saale): Mitteldeutscher Verlag, 2015).

6 Florian Steger and Maximilian Schochow, Traumatisierung durch politisierte Medizin. Geschlossene Venerologische Stationen in der DDR (Berlin: MWV Medizinisch Wissenschaftliche Verlagsgesellschaft, 2015).

7 Maximilian Schochow and Florian Steger, "Closed Venereology Wards in hospitals of the German Democratic Republic (GDR) and the Ministry for State Security (MfS)," Journal of the European Academy of Dermatology \& Venereology no. 31 (2017), pp. e225-226. 
In the article, six questions have been put forward: 1. What was the legal basis for the compulsory commitment to the closed venereology wards in the SOZ and the GDR? 2. How were these wards structured and what was their function? 3. What was the procedure for admission to the wards? 4. What were the characteristics of women admitted? 5. How did the daily life in the closed venereology wards look like? 6. What were the relationships between physicians working at the wards and the Ministry of State Security?

\section{Method}

On the basis of extensive archival research and narrative interviews with contemporary witnesses, it was possible to reconstruct the history of the closed venereology wards at Halle (Saale) and Leipzig-Thonberg. Most of the official sources analysed were found in the city archives (Stadtarchiv) of Halle (Saale) and Leipzig, as well as in the federal archives (Bundesarchiv) in Berlin. Official sources of the Federal Commissioner for the Records of the State Security Service of the former German Democratic Republic (short: Stasi Records Agency; German: BStU) were also inspected; those were specifically provided for the research by the regional offices in Halle (Saale) and Magdeburg.

In addition, patient records from the closed venereology ward LeipzigThonberg stored in the Municipal Archive in Leipzig were analysed. These records were created between 1946 and 1990. They document the situation in the closed venereology ward Leipzig-Thonberg. It can be assumed that inventory contains approximately 5,000 records. The inventory is sorted alphabetically, based on surnames of the compulsory committed women. The analysis allows a reconstruction of the events in the closed venereology ward and permits a further approach to the history of medicine of the former German Democratic Republic. These sources were examined employing the historical-critical method.

Furthermore, a qualitative analysis of narrative interviews conducted with contemporary witnesses was performed. ${ }^{8}$ The interviewees included former patients, physicians and nurses from the closed venereology wards, as well as officers of the GDR transit police (Transportpolizei).

8 Aleida Assmann, Erinnerungsräume. Formen und Wandlungen des kulturellen Gedächtnisses (München: C.H. Beck, 2009). 


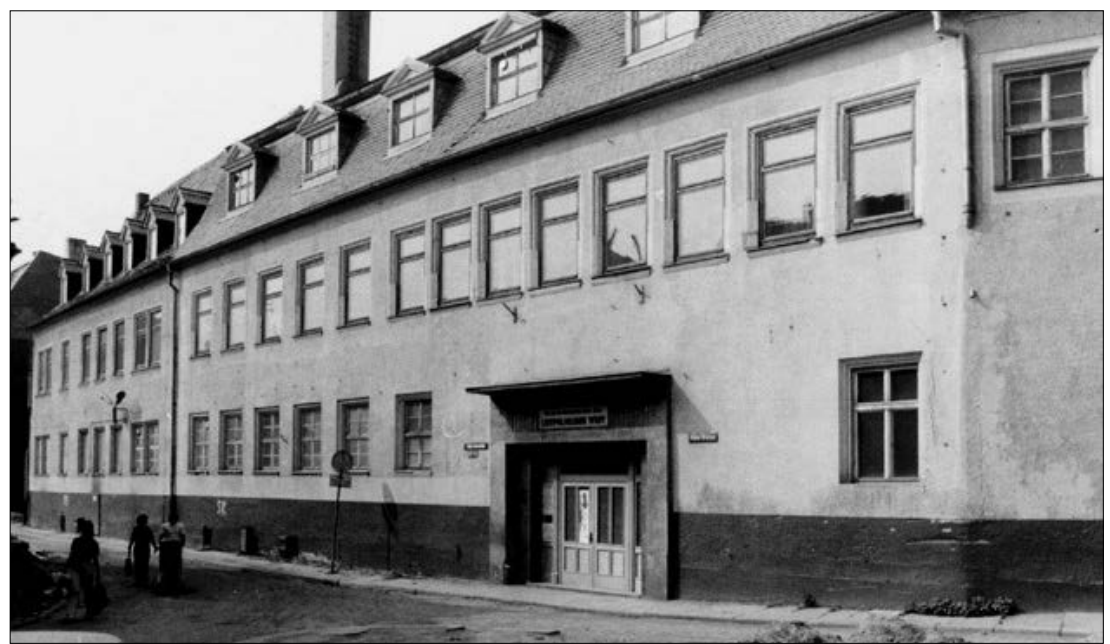

Closed venereology wards in Halle (Saale), 1980

The interviews were rendered anonymous before transcribing them. Critical source analysis made the necessary contextualization of the experiences described in the interviews possible. Simultaneously, testimonies from the interviews constituted a corrective to the written sources. Synthesis of the two qualitative methods allowed for reconstruction of events on the closed venereology wards in Halle (Saale) and Leipzig-Thonberg.

\section{Legal Basis for the Compulsory Commitment in the Soviet Occupation Zone and German Democratic Republic}

The idea that closed venereology wards should serve to prevent STDs was widely accepted during the Weimar Republic. Since 1927, a law on combatting venereal diseases existed in the Weimar Republic. This law was also in power in the SOZ until 1947 and in the Western Occupation Zones. It continued to thrive in the Federal Republic of Germany (FRG). In the SOZ after the end of the Second World War, the Soviet healthcare system was implemented. ${ }^{9}$ In addition to the still existing Weimar law,

\footnotetext{
9 Heike Krumbiegel, Polikliniken in der SBZ/DDR. Konzeption und Umsetzung öffentlicher, poliklinischer Einrichtungen unter der besonderen Berücksichtigung Brandenburgs (Frankfurt am Main: VAS, 2007).
} 
the instructions 25, 30 and 273 of the Soviet Military Administration in Germany (SMAG) were put into effect. These demanded "combat against people who belong to the German population and suffer from venereal diseases" and intended measures in order to combat venereal diseases based on the model of the Soviet healthcare system. ${ }^{10}$ These measures included training of dermatologists and venereologists, compulsory hospitalisation of people suffering from venereal diseases as well as the establishment of closed facilities. ${ }^{11}$ In the early 1960s during GDR times, the instructions 25, 30 and 273 of the SMAG were invalidated by the "Regulation for the Prevention and Control of Venereal Diseases". ${ }^{12}$ This GDR-regulation, which came into effect on February 23 $3^{\text {rd }}$, 1961, partly followed SMAG instructions, for instance, the multilevel procedure of compulsory hospitalisation into closed venereology wards. On the grounds of this regulation, the hospitalised could be individuals who had resisted medical treatment, who had repeatedly been documented as suffering from venereal diseases, and who were under suspicion of promiscuous behavior. If people evaded hospitalisation, they stood a chance of being institutionalised in a closed venereology ward. ${ }^{13}$

\section{Structure and Function}

All closed venereology wards were permanently locked by a barred door. Entering the closed venereology ward in Halle (Saale), one saw an iron cage with a wooden stool inside. A long hallway followed, leading to a bathroom, a treatment room, a day room, and several patient rooms. Each patient room had five beds, a table and several chairs. ${ }^{14}$

10 Maximilian Schochow, Zwischen Erziehung, Heilung und Zwang. Geschlossene Venerologische Einrichtungen in der SBZ/DDR (Halle (Saale): Mitteldeutscher Verlag, 2019).

11 Maximilian Schochow and Florian Steger, "Die Patientenakten der geschlossenen Venerologischen Einrichtungen Leipzig-Thonberg (1946-1990)," Medizinhistorisches Journal no. 53 (2018), pp. 98-124.

12 "Verordnung zur Verhütung und Bekämpfung von Geschlechtskrankheiten vom 23. Februar 1961," Gesetzblatt der Deutschen Demokratischen Republik, Teil II (Berlin: VEB Deutscher Zentralverlag, 1961) pp. 85-89.

13 Florian Steger and Maximilian Schochow, Traumatisierung durch politisierte Medizin.

14 Interview with Mrs. HZA led by Florian Steger and Maximilian Schochow, Halle (Saale), December 11, 2013. 


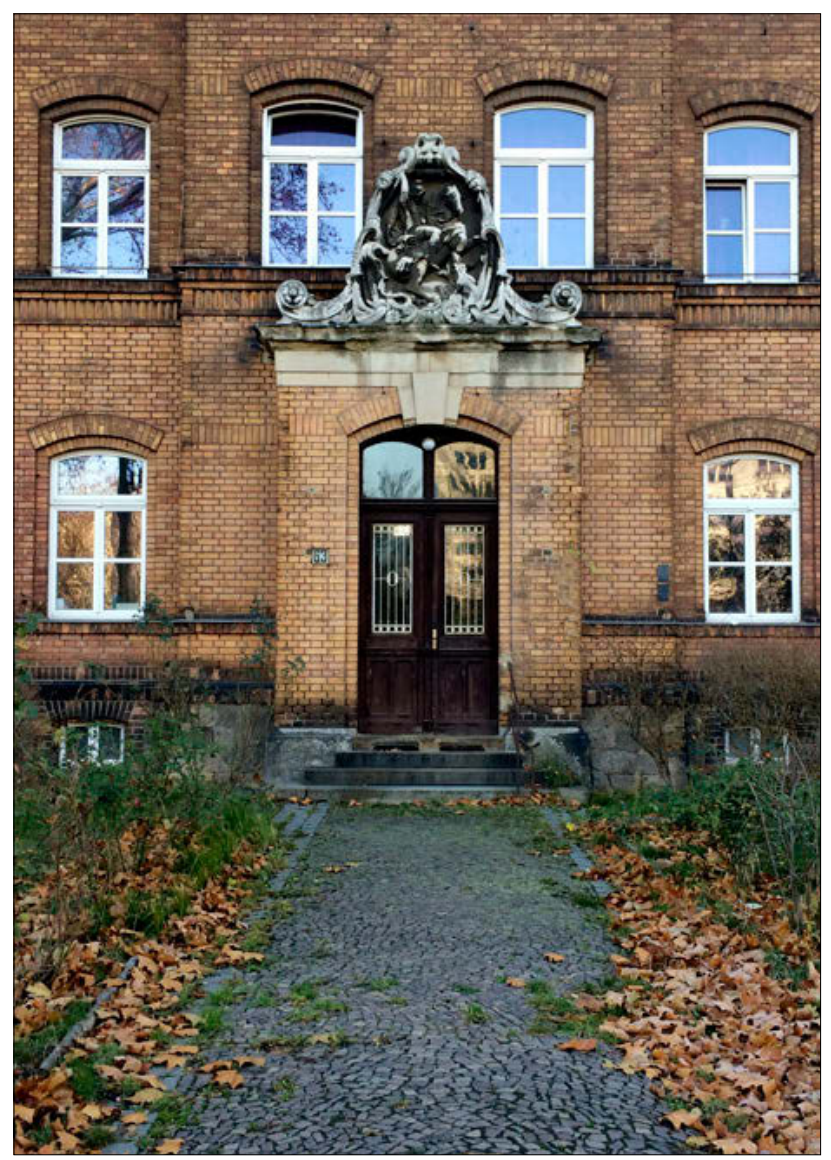

Closed venereology ward Leipzig-Thonberg, 2015

The walls were bare, the windows barred, the air stale. The ward had 30 beds, which were occupied most of the time. The closed venereology ward in Leipzig-Thonberg was comprised of a day room, several dormitories with a total of 30 beds, one bathroom, a nurses' room and an examination room. In Leipzig-Thonberg, the windows also had bars. Both the doors and windows lacked handles and knobs. ${ }^{15}$

15 Interview with Mrs. LPA led by Florian Steger and Maximilian Schochow, Halle (Saale), December 11, 2013. 
The function of the closed venereology wards was outlined in their respective house rules. The "House rules for the patients of the closed venereology ward for women of the central city hospital Halle (S)" can serve as an example. ${ }^{16}$ This set of regulations defines both the aims of the ward and the guidelines for the daily life of the women committed to it. The preamble formulates the aims of the ward. First of all, individuals suspected of being infected with an STD were to be temporarily isolated. Moreover, through "an educative influence ... it shall be attained that these citizens, subsequent to their release from the hospital, will obey the laws of our country, show a positive discipline at work, and behave in our society according to the principles of socialist existence." 17 Finally, the preamble stipulated that "[t]he duration of the stay in the closed ward is necessary for the recognition and the complete cure of their illness, as well as for the preparation of their further life." 18 This preamble consequently points out the purpose of the closed venereology ward as an isolating and educating institution for the compulsory committed women.

The main emphasis is being put on education towards a "socialist personality". ${ }^{19}$ Furthermore, the house rules specify how the women's education was to be realised: through a cleverly devised system of various means and actions. These did not solely consist of negative sanctions; commendations for good behavior and discipline at work were also envisaged. ${ }^{20}$ The disciplinary measures served the purpose of bending women's will and breaking any resistance against their compulsory hospitalisation. ${ }^{21}$ Only the last section of house rules mentioned the medical purpose of the institution, namely diagnosis and cure of illnesses.

16 BArch Best. DQ 1. Nr. 4228, Hausordnung. Für die Patientinnen der geschlossenen Geschlechtskranken Frauenstation im Stadtkrankenhaus Mitte Halle (S) Kleine Klausstr. 16, Halle (Saale), den 23. April 1963, pp. 1-6.

17 Ibid.

18 Ibid.

19 Peter Eckardt, "Erziehung zur sozialistischen Persönlichkeit. Erziehung in der DDR" in Geschlossene Heimunterbringung im Kontext sozialistischer Erziehung in der DDR ed. Juliane Thieme (Torgau: Initiativgruppe Geschlossener Jugendwerkhof, 2006), pp. 13-22.

20 BArch Best. DQ 1. Nr. 4228, Hausordnung.

21 Maximilian Schochow, Zwischen Erziehung, Heilung und Zwang. 


\section{Women of the Closed Venereology Wards}

In 1968 alone, 2,763 women were committed to closed venereology wards in the GDR. ${ }^{22}$ Only $28 \%$ of them had been diagnosed with and were treated for an STD. Put differently, $72 \%$ of the women were not suffering from an STD. ${ }^{23}$ To take another example, in 1977, 235 women from Halle (Saale) and its surroundings were committed to the closed venereology ward at the central policlinic Halle (Saale). ${ }^{24}$ Altogether, about 5,000 women were committed to this closed venereology ward during its 21 years of existence. In the interviews conducted for the purpose of this research, medical trainees, nurses, and staff members pointed out that some of the girls were 12 or 13 years old. ${ }^{25}$ By contrast, the oldest women were 72 years of age. ${ }^{26}$

In the closed venereology ward Leipzig-Thonberg, it is possible to formulate very precise statements about the characteristics of the committed women. Based on the justification for compulsory commitment, which is documented in patients' records of this institution in the form "Notification of cessation of inpatient treatment", one can distinguish following five groups of persons (see Table 1).

Patient records of this ward were evaluated for two separate time periods. The first investigated period (June 1946 to February 1961) refers to the period during which the SMAG Orders 30 and 273 were valid. The second investigated period (March 1961 to August 1990) refers to the period during which "Regulation for the Prevention and Control of Venereal Diseases" of the GDR was valid. Evaluation of patient records for both investigated periods shows the following changes in the groups of compulsory committed individuals (see Table 2).

22 Günter Elste and L. Krell, "Zur Bedeutung der Verhütungs- und Bekämpfungsmaßnahmen von Geschlechtskrankheiten in der DDR bei 'uneinsichtigen Gefährdeten und Kranken,,” Dermatologische Monatsschrift no. 156 (1970), pp. 932-938.

23 Ibid.

24 Gerd Münx, Hartmut Bruns, Gottfried Rudolf, "Venerische Erkrankungen und ihre Prophylaxe in der Stadt Halle" in Prophylaxe im industriellen Ballungsgebiet Halle. Beitrag des kommunalen Gesundheitswesens der Stadt Halle und der MartinLuther-Universität Halle-Wittenberg zum 30. Jahrestag der Gründung der Deutschen Demokratischen Republik, ed. Klaus Magyar (Halle: Abteilung Gesundheits- und Sozialwesen, 1979), pp. 69-72.

25 Interview with Mrs. HZA led by Florian Steger and Maximilian Schochow, Halle (Saale), December 11, 2013; Interview with Mrs. HZH led by Maximilian Schochow, Halle (Saale), May 13, 2014.

26 Interview with Mrs. HZH led by Maximilian Schochow, Halle (Saale), May 13, 2014. 
Table 1. Groups of persons and description

\begin{tabular}{ll}
\hline \multicolumn{1}{c}{$\begin{array}{c}\text { Groups } \\
\text { of persons }\end{array}$} & \multicolumn{1}{c}{$\begin{array}{c}\text { Description } \\
\text { in the patient records }\end{array}$} \\
\hline Prostitutes & - sexual intercourse against payment \\
& - secret prostitutes \\
& - prostitutes \\
& - suspicion of prostitution \\
& - sexually promiscuous individuals \\
Sexually promiscuous & - untreated sexually promiscuous individuals \\
individuals (German: & - suspicion of sexual promiscuity \\
HwG-Personen) & - leaving the working place without permission \\
\hline Female drifters & - drifting \\
& - vagrancy \\
& - source of infection, untreated source of infection \\
& - follow-up inspection, neglected follow-up inspection \\
& - gonorrhea, suspicion of gonorrhea \\
Individuals with & - gonorrhea and syphilis, suspicion of gonorrhea and syphilis \\
venereal diseases & - syphilis, suspicion of syphilis \\
& - permanent runaway \\
& - sexual intercourse during period of restriction \\
& - prisoner \\
\hline Other & - no entry \\
\hline
\end{tabular}

Table 2. Distribution of compulsory commitments (absolute numbers and percentage)

\begin{tabular}{lcc}
\hline \multicolumn{1}{c}{ Groups of persons } & $\begin{array}{c}\text { Validity } \\
\text { of the SMAG orders, } \\
\text { June 1946 to February 1961 } \\
\text { (n= 386) }\end{array}$ & $\begin{array}{c}\text { Validity } \\
\text { of the GDR Regulation, } \\
\text { March 1961 to August 1990 } \\
\text { (n= 855) }\end{array}$ \\
\hline Prostitutes & $11(3 \%)$ & $24(3 \%)$ \\
\hline $\begin{array}{l}\text { Sexually promiscuous } \\
\text { individuals }\end{array}$ & $51(13 \%)$ & $80(9 \%)$ \\
\hline Female drifters & $23(6 \%)$ & $445(52 \%)$ \\
\hline $\begin{array}{l}\text { Individuals with } \\
\text { venereal diseases }\end{array}$ & $289(75 \%)$ & $273(32 \%)$ \\
\hline Other & $12(3 \%)$ & $33(4 \%)$ \\
\hline
\end{tabular}

SMAG - Soviet Military Administration in Germany, GDR - German Democratic Republic. 
Evaluation of patient records from Leipzig-Thonberg shows that both in the first as well as in the second period the number of prostitutes and sexually promiscuous individuals among the compulsory committed women was very low. In the first period (June 1946 to February 1961), 11 (3 \%) prostitutes and $51(13 \%)$ sexually promiscuous individuals were found in patient records. In the second period (March 1961 to August 1990), $24(3 \%)$ prostitutes and $80(9 \%)$ sexually promiscuous individuals were identified among the analysed patient records from Leipzig-Thonberg. This refutes the assertion that most compulsory committed women were prostitutes or sexually promiscuous individuals. ${ }^{27}$ The distinction between these two groups becomes clear through description in the patient records. Those denoted as prostitutes were women who had sexual intercourse for payment or had engaged in fornication for material gains. In case of sexually promiscuous individuals, the payment or acquisition of money was not emphasised. Rather, sexually promiscuous individuals were indicated as persons who were characterised by a "constant and rapid change and absolute randomness with respect to contact with a respective partner". The "rapid change" was understood by some physicians as having four distinct partners in a period of three months. ${ }^{28}$ Other physicians identified having three distinct partners in one month as a "rapid change". ${ }^{29}$

Rather than prostitutes and sexually promiscuous individuals, in the first period in Leipzig-Thonberg 289 (75\%) women, who were compulsory committed on the grounds of having a venereal disease, made up the majority of those confined. In the second period, the distribution of groups changed. Between March 1961 and August 1990 in LeipzigThonberg, in addition to 33 (4\%) women with venereal diseases, primarily 445 (52\%) female drifters were confined. The reason for these changes was the new function of the closed venereology wards. In the first period, the function was the coercive treatment of sexually transmitted diseases. Only in the second period, the closed venereology wards

27 Uta Falck, VEB Bordell. Geschichte der Prostitution in der DDR (Berlin: Ch. Links Verlag, 1998); Steffi Brüning, Prostitution in der DDR. Eine Untersuchung am Beispiel der Städte Rostock, Berlin und Leipzig von 1968 bis 1989 (Berlin: be.bra wissenschaft, 2019).

28 Günter Räscke, "Ergebnisse einer Befragung von 100 weiblichen HwG-Personen," Zeitschrift für ärztliche Fortbildung no. 24 (1963), pp. 1356-1366.

29 W. Krüger, "Das Problem des häufig wechselnden Geschlechtsverkehrs," Das deutsche Gesundheitswesen no. 36 (1955), pp. 1200-1206. 
assumed the educational function. ${ }^{30}$ In 1972, the closed venereology ward in Erfurt was explicitly required to have an educational programme led by a pedagogue. ${ }^{31}$ The background for this development was the implementation of the "Ten Commandments of Socialist Morality and Ethics". These were incorporated into the programme of the Socialist Unity Party of Germany (German: Sozialistische Einheitspartei Deutschlands, SED) in 1963 and were considered the basis of education towards the "socialist personality". The commandments intended, among other things, to ensure people's health, to educate them to orderly behavior, and to improve social hygiene. ${ }^{32}$ With the change in function of the closed venereology wards in the GDR, changes in the groups of the compulsory committed individuals are visible. The closed venereology wards no longer served primarily for therapy, but for the education of so-called "drifters". The term "drifter" was used in the SOZ and the GDR to characterize persons who avoided regular work despite being able to work. This designation was based on a tradition dating back to the era of National Socialism. ${ }^{33}$ During the period of National Socialism and later in the SOZ and the GDR, drifters were regarded as antisocial. ${ }^{34}$

Medical care for women is documented in patient records in the form "Treatment sheet". Information about implemented therapies for gonorrhoea and/or syphilis can also be found in these forms. The evaluation of the patient records for the two periods shows the following developments (Table 3): in the group of prostitutes, the change during both periods is rather small. The proportion of implemented therapies here is relatively high with $64 \%$ in the first period and $54 \%$ in the second period. On the other hand, the other groups of persons, for example, the group of sexually promiscuous individuals, show variation: between June 1946 and February 1961, the proportion of persons treated for venereal diseases was more than

30 Maximilian Schochow, Zwischen Erziehung, Heilung und Zwang; Florian Steger and Maximilian Schochow, Traumatisierung durch politisierte Medizin.

31 H. Kittlaus and F. Schiller, "Untersuchungen an weiblichen Personen einer geschlossenen venerologischen Abteilung mit Hilfe des Maudsley Meclical Questionnaire (MMQ)," Dermatologische Monatsschrift no. 108 (1972), pp. 78-89.

32 Verena Zimmermann, "Den neuen Menschen schaffen”. Die Umerziehung von schwererziehbaren und straffälligen Jugendlichen in der DDR (1945-1990) (Köln, Weimar, Wien: Böhlau, 2004).

33 Wolfgang Ayaß, “Asoziale” im Nationalsozialismus (Stuttgart: Klett-Cotta, 1995).

34 Sven Korzilius, “Asoziale” und "Parasiten” im Recht der SBZ, DDR. 
two-thirds (80\%), whereas between March 1961 and August 1990 it fell to less than one-third (24\%). A similar change can be observed in the group of female drifters. In this group, the proportion of implemented therapies dropped from $70 \%$ to $22 \%$. In other words, the proportion of individuals who did not receive therapy for venereal disease increased from well below one-third in the period from June 1946 to February 1961 to almost twothirds in the period between March 1961 and August 1990 (see Table 3).

In addition, it became clear that in Leipzig-Thonberg the proportion of individuals being treated for venereal diseases fell significantly. Between June 1946 and February 1961, nearly two-thirds of the compulsory committed women were treated, while between March 1961 and August 1990, treatments amounted only to one-third of the committed.

Table 3. Distribution of implemented therapies

(absolute numbers and percentage)

\begin{tabular}{|c|c|c|c|}
\hline Groups of persons & $\begin{array}{c}\text { Therapy for } \\
\text { gonorrhea } \\
\text { and/or syphilis }\end{array}$ & No therapy & No information \\
\hline \multicolumn{4}{|c|}{ Validity of the SMAG orders, June 1946-February $1961(n=386)$} \\
\hline Prostitutes $(n=11)$ & $7(64 \%)$ & $4(36 \%)$ & - \\
\hline $\begin{array}{l}\text { Sexually promiscuous } \\
\text { individuals }(\mathrm{n}=51)\end{array}$ & $41(80 \%)$ & $5(10 \%)$ & $5(10 \%)$ \\
\hline Female drifters $(n=23)$ & $16(70 \%)$ & $6(26 \%)$ & $1(4 \%)$ \\
\hline $\begin{array}{l}\text { Individuals with venereal } \\
\text { diseases }(n=289)\end{array}$ & $230(79 \%)$ & $51(18 \%)$ & $8(3 \%)$ \\
\hline Other $(n=12)$ & $4(33 \%)$ & $2(17 \%)$ & $6(50 \%)$ \\
\hline \multicolumn{4}{|c|}{ Validity of the GDR Regulation, March 1961-August $1990(\mathrm{n}=855)$} \\
\hline Prostitutes $(n=24)$ & $13(54 \%)$ & $9(38 \%)$ & $2(8 \%)$ \\
\hline $\begin{array}{l}\text { Sexually promiscuous } \\
\text { individuals }(\mathrm{n}=80)\end{array}$ & $19(24 \%)$ & $54(67 \%)$ & $7(9 \%)$ \\
\hline Female drifters $(n=445)$ & $96(22 \%)$ & $331(74 \%)$ & $18(4 \%)$ \\
\hline $\begin{array}{l}\text { Individuals with venereal } \\
\text { diseases }(n=273)\end{array}$ & $119(44 \%)$ & $144(53 \%)$ & $10(3 \%)$ \\
\hline Other $(n=33)$ & $3(9 \%)$ & $9(27 \%)$ & $21(64 \%)$ \\
\hline
\end{tabular}

SMAG - Soviet Military Administration in Germany,

GDR - German Democratic Republic. 
Another interesting aspect to look at is the development of age distribution. The patient records contain both the date of birth and the date of the compulsory commitment. Therefore, the age of the persons who were compulsory committed can be determined at the time of the first admission to the ward. The evaluation for the two periods shows the following age distribution (see Table 4).

The evaluation of medical records shows that during the first period mostly adult persons (above 18 years of age) were compulsory committed. The average age of 22.5 years at the time of compulsory commitment is well above the threshold of legal age. A change in this respect can be observed in the second period. The proportion of committed adults decreases while the proportion of minors rises. The average age was 19.5 years. The comparison of the two periods shows that in the second period not only prostitutes and sexually promiscuous individuals but also individuals from other groups were younger at the time of their first commitment.

Table 4. Age distribution (absolute numbers and percentage)

\begin{tabular}{|c|c|c|c|}
\hline Groups of persons & Minors, $\mathbf{n}$ & Adults, $\mathbf{n}$ & $\begin{array}{c}\text { Average age, } \\
\text { years }\end{array}$ \\
\hline \multicolumn{4}{|c|}{ Validity of the SMAG orders, June 1946-February $1961(n=386)$} \\
\hline Prostitutes $(n=11)$ & - & $11(100 \%)$ & 28 \\
\hline $\begin{array}{l}\text { Sexually promiscuous } \\
\text { individuals }(\mathrm{n}=51)\end{array}$ & $6(12 \%)$ & $45(88 \%)$ & 24 \\
\hline Female drifters $(n=23)$ & $5(22 \%)$ & $18(78 \%)$ & 23 \\
\hline $\begin{array}{l}\text { Individuals with venereal } \\
\text { diseases }(n=289)\end{array}$ & $35(12 \%)$ & $254(88 \%)$ & 22 \\
\hline Other $(n=12)$ & $1(8 \%)$ & $11(92 \%)$ & 23 \\
\hline \multicolumn{4}{|c|}{ Validity of the GDR Regulation, March 1961-August $1990(\mathrm{n}=855)$} \\
\hline Prostitutes $(n=24)$ & $4(17 \%)$ & $20(83 \%)$ & 22 \\
\hline $\begin{array}{l}\text { Sexually promiscuous } \\
\text { individuals }(\mathrm{n}=80)\end{array}$ & $21(26 \%)$ & $59(74 \%)$ & 20 \\
\hline Female drifters $(n=445)$ & $232(52 \%)$ & $213(48 \%)$ & 19 \\
\hline $\begin{array}{l}\text { Individuals with venereal } \\
\text { diseases }(n=273)\end{array}$ & $85(31 \%)$ & $188(69 \%)$ & 21 \\
\hline Other $(n=33)$ & $14(43 \%)$ & $19(57 \%)$ & 20 \\
\hline
\end{tabular}

SMAG - Soviet Military Administration in Germany, GDR - German Democratic Republic. 
Since the 1960s, these young girls were considered particularly promiscuous and easily manageable in education. ${ }^{35}$ High promiscuity was considered a reason for the spread of venereal diseases. In order to prevent such spread, young girls were often compulsory committed without any medical indication and educated.

In Leipzig-Thonberg, the proportion of prostitutes was about $3 \%$ during both periods (June 1946 to February 1961) and (March 1961 to August 1990). The proportion of sexually promiscuous individuals was $9 \%$ in the first and $13 \%$ in the second period. It is clear that in Leipzig-Thonberg scarcely any prostitutes and sexually promiscuous individuals were compulsory committed, but rather women with venereal diseases, women suspected of having a venereal disease, and, most prominently, female drifters. While these women were defamed as prostitutes, in reality they were victims of the SED dictatorship.

\section{Committal and Admission}

Contemporary witnesses reported the manner in which they were arbitrarily taken into custody by the police and immediately committed to a closed venereology ward, for example, during hitchhiking trips. ${ }^{36}$ A suspicion of loitering, often in combination with the accusation of prostitution, was a common pretext for hospitalisation of women in closed venereology wards. Other reasons included a failure to appear at an ordered medical examination, treatment or follow-up examination. Finally, women were committed to closed venereology wards when caught in engaging in sexual intercourse or related acts with other individuals even though medical authorities had ordered them to refrain from doing so because of a STD diagnosis. ${ }^{37}$ Often women were denounced by a third party.

According to the house rules in Halle (Saale), upon admission to a closed venereology ward, the women had to hand over all their identity papers, valuables - such as watches, rings and cash - as well as personal

35 Sigrid Jenke, L. Krell, D. Kesler and Günter Elste, "Weitere Untersuchungen über Uneinsichtige, Gefährdete und Kranke aus dem Fachbereich Venerologie," Deutsches Gesundheitswesen no. 32 (1977), pp. 418-420.

36 Interview with Mrs. HPC led by Florian Steger and Maximilian Schochow, Halle (Saale), January 29, 2014.

37 Interview with Mrs. HZB led by Florian Steger and Maximilian Schochow, Halle (Saale), January 9, 2014. 
items including their clothes to a nurse. These objects were kept in a stockroom for personal effects. ${ }^{38}$ After the women had parted with their belongings, they were supposed to wash themselves and put on the institutional clothing. Some women's hair was cut at this point. An admission interview followed, during which the women had to provide information about the reasons that had led to their commitment to the closed venereology ward. An initial gynecological examination ensued, which typically the ward's director conducted assisted by nurses. The women were not informed about the medical treatment at any point during their hospitalisation; it was performed without their consent. The gynecological examinations were humiliating and caused physical pain. The women entered the treatment room without any clothes on and were examined on a gynecological chair. Many recall the painful vaginal insertion of a glass tube of considerable girth. ${ }^{39}$ Bleeding and defloration were frequent side-effects. The witnesses' testimonies point to the brutality of the examinations. After a swab test, some of the women were injected with a fever-inducing drug (likely "Pyrexal"). Fever injections were customary at the time; they were also put into practice outside of the closed venereology contexts. ${ }^{40}$ They were intended to trigger a possible infection that would bring out the gonococci for the swab test. The injections often resulted in nausea and high fever. Following the examination, the women were assigned to their beds. ${ }^{41}$

In Halle (Saale) and Leipzig-Thonberg alike, welfare workers and the police committed women to the closed venereology wards. Many inmates were quite young. Just the suspicion of prostitution alone sufficed for an admission to the ward. ${ }^{42}$ Hospitalisations oftentimes constituted a breach of the respective GDR law. However, in some cases women were committed to the closed venereology wards in accordance with the GDRlaw. The methods of admission were the same in both wards. The admission process inevitably culminated in a de-individualising gynecological examination.

38 BArch Best. DQ 1. Nr. 4228, Hausordnung.

39 Interview with Mrs. HPC led by Florian Steger and Maximilian Schochow, Halle (Saale), January 29, 2014.

40 Wolfgang Gertler, Systematische Dermatologie und Grenzgebiete, 3 Bände (Leipzig: Thieme, 1973).

41 Interview with Mrs. HPE led by Florian Steger and Maximilian Schochow, Halle (Saale), January 30, 2014.

42 Interview with Mrs. HPA led by Florian Steger and Maximilian Schochow, Halle (Saale), December 11, 2013. 


\section{Daily Life and Daily Terror at the Wards}

The women had to get up before 6 a.m. ${ }^{43}$ A daily gynecological examination followed. For this purpose, all inmates had to stand in line outside the treatment room and wait for their turn. ${ }^{44} \mathrm{~A}$ swab test was taken with a sizable glass tube, which often caused severe injuries. During the treatment period of four to six weeks, every woman was examined on a daily basis and had to produce up to 30 negative swab test results in order to be discharged. Breakfast was served by the nurses following the gynecological examination at 8 a.m. ${ }^{45}$ Afterwards, the women were obliged to participate in occupational therapy. This mainly consisted of cleaning chores within the venereology ward as well as in the central policlinic. Some contemporary witnesses reported that they were assigned to do the laundry and clean the toilets. ${ }^{46}$ The women also had to work in the afternoons, mostly outside of the closed venereology ward and central policlinic. They had to return by 7 p.m. ${ }^{47}$ Dinner followed, with lock-up time being set at 9 p.m.

The testimonies regarding hospitalisation, admission and (medical) treatments on the closed venereology ward in Leipzig-Thonberg match the accounts on the ward in Halle (Saale). Women were committed in similar ways and for alike reasons and their daily life was similar as well. For the 1970s; however, it is documented that the women in LeipzigThonberg were not forced to do compulsory work. ${ }^{48}$ After finishing breakfast, the women were to return to their rooms or allowed to stay in the day room. One former inmate recalled how she could not find any meaningful activity. There was nothing which to keep oneself busy with. The women just sat in the rooms of the closed wards with nothing to do. ${ }^{49}$

43 Interview with Mrs. HPA led by Florian Steger and Maximilian Schochow, Halle (Saale), December 11, 2013.

44 Interview with Mrs. HPE led by Florian Steger and Maximilian Schochow, Halle (Saale), January 30, 2014.

45 Interview with Mrs. HZA led by Florian Steger and Maximilian Schochow, Halle (Saale), December 11, 2013.

46 Ibid.

47 Ibid.

48 Interview with Mrs. LPK led by Florian Steger and Maximilian Schochow, Halle (Saale), November 26, 2014.

49 Interview with Mrs. LPA led by Florian Steger and Maximilian Schochow, Halle (Saale), December 11, 2013. 
Both wards aimed to integrate the women into a well-regulated daily routine, for which the medical examinations were crucial. One key difference though was certainly the organisation of daily routines. While education through work was central in Halle (Saale), the women in LeipzigThonberg were more or less simply kept under lock and key. There is some evidence to suggest that in Leipzig-Thonberg, the gynecological examinations were at least executed with greater care and that the staff there implemented fewer sanctions for the female inmates.

At the closed venereology ward in Halle (Saale), the patients' isolation and a strictly hierarchical, internal order led to a system of daily terror. Isolation was created by banning all contact with the outside world. ${ }^{50}$ At the top of the hierarchical structure was the medical director of the central policlinic and the head of the closed venereology ward. Young girls were at the bottom of that order, which meant that in addition to the brutal medical examinations, they were also harassed by senior inmates. The hierarchy was installed and maintained by a terror within the terror, which permeated the entire history of the closed venereology ward. The head of the ward in Halle (Saale) was described as having been tyrannical, gruff, and distant. ${ }^{51}$ Members of the medical staff assumed a domineering and paternalistic attitude towards the women. ${ }^{52}$ Overall, the medical staff treated patients in a distant and degrading manner with little regard for the individual.

During (medical) examinations and treatments, the inmates were abused and hurt on purpose. Moreover, the women were brought to heel through a game of rewards (such as increased cigarette rations) and punishments (e.g., having to spend the night on a stool instead of a bed). The relationships among inmates were also hierarchically organised. The house rules encouraged such a hierarchical order by implementing a seniority system. It meant that senior inmates assigned duties inside or outside the ward, assisted the medical staff with (medical) treatments and supervised disciplinary actions. In fact, senior inmates cooperated with the medical staff in order to receive preferential treatment. ${ }^{53}$ In this system of terror within the terror,

50 BArch Best. DQ 1. Nr. 4228, Hausordnung.

51 Interview with Mrs. HZB led by Florian Steger and Maximilian Schochow, Halle (Saale), January 9, 2014.

52 Interview with Mr. HZG led by Florian Steger and Maximilian Schochow, Halle (Saale), April 8, 2014.

53 Interview with Mrs. HZA led by Florian Steger and Maximilian Schochow, Halle (Saale), December 11, 2013. 
the violence that the senior inmates experienced would thus immediately be handed down to their younger peers. Upon their discharge from the closed venereology ward, the women were made to sign a confidentiality agreement report to the welfare office in their home town. The confidentiality agreement is another aspect of the closed venereology wards that is reminiscent of prison-like structures.

The women were traumatised by being committed to the ward. ${ }^{54}$ Immediate and long-term damage can be observed. Immediate damage meant, among others, that during the initial gynecological examination many women were deflowered. Many contemporary witnesses furthermore report that they experienced the procedure of the swab test as an act of punishment. Resulting from the injection of the provocation agent, many women complained about nausea, diarrhea, vomiting, fatigue, headaches, long-term paralysis, and shivering fits. ${ }^{55}$ In addition to that, contemporary witnesses described long-term effects such as an overall fear of gynecological examinations or physicians in general. A lot of women still suffer from insomnia, sexual reluctance, and incontinence. Many biographies reveal a certain inability to form functioning long-term relationships, which might very well have resulted from the stay in the closed venereology ward. One contemporary witness reported living in frequently changing partnerships. Although this contemporary witness had children from different partners, she was unable to establish lasting bonds with the respective fathers. Other women reported that they had remained childless.

\section{Physicians and the MfS: Reports of the Unofficial Informant Schneider and Karl}

In early 1976, the MfS had recruited a physician at the polyclinic in Halle (Saale) who was active under code-name "Schneider". ${ }^{56}$ Informant Schneider was instructed to report in detail on his colleagues. He was supposed to account for both work-related and private issues. Within

54 Stefan Trobisch-Lütge and Karl-Heinz Bomberg, eds., Verborgene Wunden. Spätfolgen politischer Traumatisierung in der DDR und ihre transgenerationale Weitergabe (Gießen: Psychosozial-Verlag, 2015).

55 Interview with Mrs. LPA led by Florian Steger and Maximilian Schochow, Halle (Saale), December 11, 2013.

56 BStU Archiv der Außenstelle Halle. MfS BV Halle. KD Halle. VIII 616/76. B1. 000006-000145. 
the following months, informant Schneider submitted explicit assessments regarding the management qualities of the director of the clinic as well as his private circumstances. The director of the clinic was also head of the closed venereology ward. Therefore, from October 1976 onwards, the MfS knew about the compulsory hospitalisations to the ward. Furthermore, it knew about the daily infringements of common law in former East Germany. For example, the report indicated four cases proving that the head of the ward infringed juridical regulations.

Moreover, informant Schneider participated in a disciplinary enquiry against the director of the polyclinic and head of the ward. ${ }^{57}$ In spring 1977, Schneider reported the results of this enquiry to the district administration of the Socialist Unity Party of Germany (Sozialistische Einheitspartei Deutschlands - SED). Consequently, the head of the clinic in Halle (Saale) was deprived of his power and continued his work only as the head of the closed venereology unit. From this time on, the reports of informant Schneider focused solely on the patients' treatment in the ward. He gave accounts of the female patients, most of them being especially drastically disciplined. ${ }^{58}$ Some patients were kept isolated in a bathroom for several days. Brawls or brutal encounters on the ward were described. Sometimes, due to lacerations or similar injuries, patients had to be moved from the ward to another unit of the hospital, so they could be treated as regular inpatients. By the end of 1978, the informant Schneider reported on the definite need for a replacement for the position of the head of the closed venereology ward. He was accused of holding a patient isolated in the bathroom for 48 hours. Consequently, woman suffered from tuberculosis and were not sufficiently medically treated. Immediately, disciplinary actions against the head of the ward followed. Further records of informant Schneider documented the discussion about who should succeed as the head of the ward. 59

Second MfS informant collaborated with the Stasi under the code name "Karl". From the late 1960s onwards, informant Karl reported regularly to the MfS. Since he was working as a doctor of the district and therefore in charge of a larger area, he was not directly concerned with

57 BStU Archiv der Außenstelle Halle. MfS BV Halle. KD Halle. VIII 616/76. B1. 000006-000145.

58 Ibid.

59 Ibid. 
the closed venereology ward. Part of his area of responsibility included to report the so-called HWG-persons. HWG meant "Sexually promiscuous individuals" (German: HwG-Personen). ${ }^{60} \mathrm{He}$ was supposed to report citizens who were suspected of displaying such promiscuous behavior. Informant Karl named first and last name, age, profession, and private address of the suspect - as well as the names of contact persons, that is, individuals the suspect was accused of having a sexual relationship with. ${ }^{61}$ Furthermore, Karl put together short dossiers about a number of patients. Those documents included information on the current occupational situation, way of living, relationships and contacts with other people. ${ }^{62}$ For example, he reported on a woman who was unemployed at the time and seemed to show promiscuous behavior. Informant Karl, in his position as a physician of the district, examined this patient at the clinic for dermatology in Magdeburg. Thereafter, the woman was involuntarily committed to the closed venereology ward in Leipzig. ${ }^{63}$ Since the early 1980s, Karl reported on all patients of the district of Schönebeck, who suffered from venereal diseases and on all men and women they had sexual contact with. In one case, Karl reported a woman who had been unemployed for more than half a year and lived together with different men. Though there seemed to be no medical indication, this woman was involuntarily committed to the closed venereology ward in Leipzig. ${ }^{64}$ His other reports from the 1980 s reveal that personal and health-related information of underaged, foreign, or chronically ill women were handed over to the MfS, with violation of medical confidentiality.

Informant Schneider mainly reported on his co-workers, especially focusing on the director of the polyclinic in Halle (Saale). Other studies on physicians working for the MfS as unofficial informants show that most of the information collected by them originated through spying on their colleagues. Therefore, the reports of informant Schneider are not unusual. His reports document the definite dismissal and following transfer of the head

\footnotetext{
60 BStU Archiv der Außenstelle Magdeburg. BV Magdeburg, KD Schönebeck. 26 II/2. 5040/61 “Karl”, B1. 000018-000367.

61 Ibid.

62 BStU Archiv der Außenstelle Magdeburg. BV Magdeburg, KD Schönebeck. 26 II/1. 5040/61 “Karl”, B1. 000169-000276.

63 Ibid.

64 Ibid.
} 
of the closed venereology ward in Halle (Saale). Accordingly, the MfS was always well informed about the events at the ward. It is possible, that the MfS was also involved in the dismissal of the director.

In comparison, the informant Karl almost exclusively informed about his patients. He provided the MfS with personal and health-related details. Hence, he violated the doctor-patient confidentiality agreement. Such violations of valid principles of law regarding medical attendance toward patients in the GDR can also be found in other studies on physicians who worked as unofficial informants for the MfS. In her work from 2008, Franziska Weil assumes that about one third of all physicians collaborating with the MfS shared private information about their patients, with clear knowledge that they would break medical confidentiality. ${ }^{65}$ However, informant Karl often went one step further. He drew up reports and dossiers that provided personal information as well as details on the health condition of the patient, for example, about contagion with gonorrhea or syphilis. Likewise, we found out that informant Karl in his reports to MfS provided information on suggested treatment or hospitalisation of his patients. Given this documentation, it is certain that the MfS knew, which patients were involuntarily committed to the closed venereology ward. However, the extent to which informant Karl reported on health related issues has to be understood as an exception. Informants not often shared medical details with the MfS. Nevertheless, within the group of spying dermatologists and venereologists, reports like those of informant Karl are not exceptional. An exceptional example can be found in the work of Franziska Weil. ${ }^{66}$ She reassembled the activity of a person called Irina, an unofficial member of the MfS on special duty (in German: Inoffizielle Mitarbeiterin im besonderen Einsatz, IME). Irina was a dermatologist and venereologist in Karl-Marx-Stadt, now Chemnitz. In 470 reports, she shared in detail personal and medical aspects of the life of her patients. ${ }^{67}$ This supports the theory that physicians who specialised in dermatology or venereology, who also worked for the MfS as unofficial informants, very often comprehensively violated the medical confidentiality.

${ }^{65}$ Francesca Weil, Zielgruppe Ärzteschaft. Ärzte als inoffizielle Mitarbeiter des Ministeriums für Staatssicherheit der DDR (Göttingen: Vandenhoeck und Ruprecht Unipress, 2008).

66 Ibid.

${ }^{67}$ Ibid. 


\section{Operational Procedures of the Informant Karl}

Informant Karl not only provided detailed information about his female patients. Among his operational procedures, there are two reports with far-reaching consequences. For one, Karl was planning opartional procedures involving dispatch of fictitious medical summons. The letters demanded citizens to appear in person for a medical examination in case they were suspected of displaying promiscuous behavior. In this regard, in 1983, informant Karl was asked by a MfS-officer, whether he would summon citizens for a medical examination. During this appointment, employees of the MfS would steal the keys of the patient's apartment. ${ }^{68}$

The doctor agreed to this procedure, proposing actions how to extend it: he additionally worked up tangible plans on how to denounce people publicly. His idea of "Zersetzung" - a very devious technique of psychological harassment - was to send the letter about the obligatory examination, signed by the clinic of dermatology, not to patients' private addresses but to their work place. ${ }^{69}$ The letter would include a note saying that the private address was unknown. Informant Karl's idea was to spread the rumor about a specific person suffering from a venereal disease as fast as possible. In case the rumor did not circulate among co-workers by itself, further measures might be applied. For instance, the police could take the suspect into custody during work. ${ }^{70}$

Such fictitious summons, forcing citizens to appear at the hospital for medical examinations, was an instrument regularly used by doctors who were unofficial informants. During the examinations, members of the MfS could go through the apartment of the patient, search their belongings or install technical bugging equipment. ${ }^{71}$ This procedure is documented in several cases. In her study from 1998, Sonja Süß ascertained that the director of a psychiatric clinic, also working for the MfS, repeatedly used this method. ${ }^{72}$ Informant Karl improved and developed this instrument and

${ }^{68} \mathrm{BStU}$ Archiv der Außenstelle Magdeburg. BV Magdeburg, KD Schönebeck. 26 II/2. 5040/61 “Karl”, Bl. 000018-000367.

69 Ibid.

70 Ibid.

71 Peter Bohley, “Operative Zersetzung” in Erlebte DDR-Geschichte. Zeitzeugen berichten, ed., Peter Bohley (Berlin: Ch. Links Verlag, 2004), pp. 161-184.

72 Sonja Süß, Politisch mißbraucht? Psychiatrie und Staatssicherheit in der DDR (Berlin: Ch. Links Verlag, 1998). 
adjusted it to the field of dermatology and venereology. Eventually, the public denunciations, proposed by informant Karl, need to be seen as a measure of psychological harassment or, to use the German term, Zersetzung. Such techniques are known to be used specifically against pastors, artists, or other opponents of the political system of the former East Germany.

The information on possible venereal diseases was misused in order to demoralise people who behaved suspiciously in the opinion of the MfS. One victim, a deacon of the Protestant Church in Halle (Saale), read in his Stasi file that the MfS knew of his possible infection with a venereal disease. A captain of the MfS contacted a physician specialising in dermatology and venereology, who also worked as an unofficial informant. ${ }^{73}$ This doctor agreed on a fake summon and on medical examining of the deacon. During the examination, the physician was instructed to ask the patient about his contacts with women. It was agreed that the deacon would receive a letter telling him to be present at the hospital. ${ }^{74}$ In case of an acute disease, it would be considered whether the patient needed to stay as an in-patient. What the MfS did not know is that the deacon obtained antibiotics from a befriended doctor and cured himself. Due to this self-therapy, the physician, who also was an informant for the MfS, could not diagnose him with an infectious disease..$^{75}$

As early as the 1970s, the MfS planned on using compulsory hospitalisations in the closed venereology wards in deliberate manner, to keep politically unconformed people throughout entire GDR territory away from attending political mega events, such as the $10^{\text {th }}$ World Festival of Youth and Students in 1973 in East-Berlin. ${ }^{76}$ During the 1980s those plans were further developed. This shows the example of the previously mentioned deacon of the Protestant Church in Halle (Saale). He was forced, under false pretenses, to appear at the ward of venereology of the hospital in Halle (Saale), with suspiction of suffering from a venereal disease. He was also supposed to be hospitalised as an in-patient.

On the one hand, the ficticious summons should lead to a temporary imprisonment of the patient as well as the exposure of possible female

73 BStU Archiv der Außenstelle Halle. MfS BV Halle. OV “Dämon”, Reg. Nr. VIII 1249/83, Archiv 3048/85, Bd. I/2, B1. 000316-000319.

74 Ibid.

75 Interview with Mr. HZA led by Maximilian Schochow, Halle (Saale), July 5, 2015.

76 Sonja Süß, Politisch mißbraucht? 
contacts. On the other hand, they were part of a psychological measure, Zersetzung, that was planned for wide utlisation. A specific department of the MfS - so called section number 26 - developed such measures. For the purposes of Zersetzung, telephone calls were protocolled, private homes were bugged, and persons of interest were controlled via video surveillance. ${ }^{77}$

\section{Conclusion}

During the 40-year existence of the GDR, multiple thousands of women were committed to closed venereology wards. With closed venereology wards, the GDR continued a tradition of medical care for persons with sexually transmitted diseases (STD) that can be traced back to the $19^{\text {th }}$ century. The idea that closed venereology wards should serve to prevent STDs was widely accepted during the Weimar Republic. However, the situation in the GDR was different. Politicized medicine in the GDR served primarily to (re)educate the involuntarily committed women. Comparison of particular closed venereology wards shows several similarities but also a number of differences. The wards in Halle (Saale) and Leipzig-Thonberg show similarities with regard to their purpose and structure as well as in the way in which women were committed and admitted to the ward. However, the daily routines in both wards differ. The system of compulsory hospitalisation to closed venereology wards established in the GDR was based on the Soviet healthcare system. Its purpose was not simply to sanction behavior that diverged from the prescribed socialist norm but also to educate women in accordance with socialist standards. The involuntarily committed women in the GDR were treated by measures of politicized medicine. This medicine was shaped and executed by actors who imposed their own standards on the victimised women daily. Moreover, all closed venereology wards in the GDR were monitored by the MfS through a network of unofficial informants. Medical care thus had the educative goal of transforming the assumed suffering persons into "socialist personalities." Such politicized medicine in the GDR can only, so far, be determined in case of the venerology wards.

77 Angela Schmole, Abteilung 26. Telefonkontrolle, Abhörmaßnahmen und Videoüberwachung (Berlin: Die Bundesbeauftragte für die Unterlagen des Staatssicherheitsdienstes der Ehemaligen Deutschen Demokratischen Republik, Abteilung Bildung und Forschung, 2009). 


\section{Slēgtās veneroloǵijas nodạ̦as Vācijas Demokrātiskajā Republikāa}

Vācijas Demokrātiskās Republikas (VDR) 40 gadu pastāvēšanas laikā desmitiem tūkstošu sieviešu nosūtīja uz veneroloǵijas nodal̦ām. Valstī ieviestā obligātā hospitalizācija slēgtās venerologijas nodaḷās bija veidota, izmantojot padomju veselības aprūpes sistēmu. Tās mērķis bija ne tikai sodīt par tādu uzvedību, kas neatbilda sociālistu noteiktajām normām, bet arī izglītot sievietes saskaņā ar sociālistu noteiktajiem standartiem. Venerologiijas nodaḷās piespiedu kārtā ievietotās sievietes VDR ārstēja, izmantojot politizēto medicīnu. Šo medicīnas tipu veidoja un vadīja personas, kas ikdienas darbā ar sodītajām sievietēm ieviesa vien sev zināmus standartus. Turklāt visas VDR slēgtās venerologiijas nodaļas uzraudzīja Valsts drošības ministrija, izmantojot neoficiālu informatoru tīklu.

Atslēgvārdi: VDR / Austrumvācija, izglītība, Valsts drošības ministrija, pacientu izolācija, pacientu un ārstu attiecības, politiskās aktivitātes, seksuāli transmisīvās slimības.

\section{Florian Steger}

Dr., profesors, Ulmas Universitātes Vēstures, filozofijas

un medicīnas ētikas institūts / Professor, Institute of the History,

Philosophy and Ethics of Medicine, Ulm University

Maximilian Schochow

$P D$ Dr., Ulmas Universitātes Vēstures, filozofijas

un medicīnas ētikas institūts / Institute of the History,

Philosophy and Ethics of Medicine, Ulm University 